\title{
Power Performance Evaluation of a PV Module Using MPPT with Fuzzy Logic Control
}

\author{
Suman Chowdhury ${ }^{l,}$, Dilip Kumar Das ${ }^{2}$ and Md Sharafat Hossain ${ }^{3}$
}

\author{
${ }^{1}$ Department of Electrical and Electronic Engineering, International University of Business Agriculture and Technology, Dhaka, \\ Bangladesh \\ ${ }^{2}$ Department of Mathematics, International University of Business Agriculture and Technology, Dhaka, Bangladesh \\ ${ }^{3}$ Department of Electrical and Electronic Engineering, Dhaka University of Engineering and Technology, Gazipur, Bangladesh
}

Received: November 16, 2020, Revised: December 18, 2020, Accepted: December 22, 2020, Available Online: January 04, 2021

\begin{abstract}
This paper exhibits performance of power of photovoltaic (PV) module in the case of shading effect. A comparison is made with performance of power of PV module void of MPPT solution. From the MATLAB simulation it is found that around $9.92 \%$ more average power generation is possible if MPPT (maximum power power point) solution is taken. To take the effect of partial shading a variation of irradiance profile has been proposed since change of irradiance causes the variation of output power to a great extent. Again to observe the performance of output power with MPPT Fuzzy logic control has been introduced for making the tracking fast and accurate. Mamdani control has been chosen as a technique for fuzzy controller. On top of this, mathematical structure of PV module has been prepared in MATLAB simulink to see output preview of PV module and this module has been linked to the fuzzy logic system to trace the peak power. In the simulation process the instantaneous power, average power and percentage power development are being analyzed with figures.
\end{abstract}

Keywords: Power, Module, MPPT, Fuzzy, PV.

This work is licensed under a Creative Commons Attribution-Non Commercial 4.0 International License.

\section{Introduction}

In the modern age renewable energy sources are playing vital role. And sun energy is treated as a best resource among all energy sources with less carbon emission [1]-[2]. That's why sun power is considered as one of big potential energy sources in earth making future aspect for consideration as inexhaustible main source of power [3]-[4]. The PV module efficiency mainly depends upon the materials used in solar cells and technical arrangement of the cells in module. At this moment, the efficiency of PV module is in range of 12 to $29 \%$ for conversion of sunlight to electricity [5]. For getting optimum energy from photovoltaic module, it is needed to run the module at maximum power using MPPT (Maximum power point tracking) followed by several common techniques like 1) perturb and observe process [6]-[8]; 2) incremental conductance process [9]-[10]; 3) fuzzy logic [11] and neural network process [12]. Implementation of fuzzy and neural networks for the control of MPPT is an outstanding field for research. These processes related to artificial intelligence are suitable for promoting the tracing capability as regard to present conventional processes [12].

Fuzzy as a part of Artificial Intelligence takes its origin by professor Lofti Zadeh who produced fuzzy set principle in 1965 [13]. Among artificial intelligence based processes fuzzy has some advantages so that the algorithm for MPPT can be obtained easily [14]. For maximization power of pv module with control of the duty cycle ratio in the profile of the PV \& IV curve. Perturb and observe method [15] as well as the incremental and conductance method utilized as the common MPPT techniques inhibits step length for selection of the duty cycle [16]. So step size controls the MPPT operation to a great extent because for small step size the tracking process goes down the speed while for the large step size the fluctuation on maximum power point occurs.

For this reason to control the step size it is important to apply the intelligence technique like fuzzy logic and adaptive neuro fuzzy technique so that step size can be adapted according to the requirement [17]-[33]. Fuzzy is normally utilized to activate system as human control in an automation fact. Fuzzy is capable for controlling step size by empirical methods and professional knowledge without the necessary understanding the detailed mathematical model of the existing plant. The input_output parameters of the required system are largely responsible to enhance effectiveness of fuzzy in determination of MPPT with control of duty cycle command.

Though there are a good number of various input variables for MPPT algorithm input, slope of PV curve for photovoltaic cell is taken as the most utilized variable of input [22]-[24],[29]. Fuzzy is considered as most preferable method for seeking the maximum power of the pv system for ensuring stability and good response rate. For better output of Fuzzy control method, researchers are more intended to find MPPT solution with the Fuzzy logic in their various publications [34]-[35]. The fuzzy inherited MPPT algorithm is provided by researcher for effectiveness \& robustness of PV system [36]-[37]. Actually the main problem is about to selection of the step size for MPPT tracking process in various methods of MPPT tracking system. In Fuzzy system this problem can be solved to a great extent since Fuzzy has a good platform to analyze the step size as the requirement base in decision making process.

In this paper the MPPT solution is made using Fuzzy logic to seek the power performance as well as effectiveness of the PV module having consideration of various factors. Also this paper tries to show the partial shading effect of photovoltaic module with MPPT solution followed by fuzzy logic control.. 


\section{Practical Model}

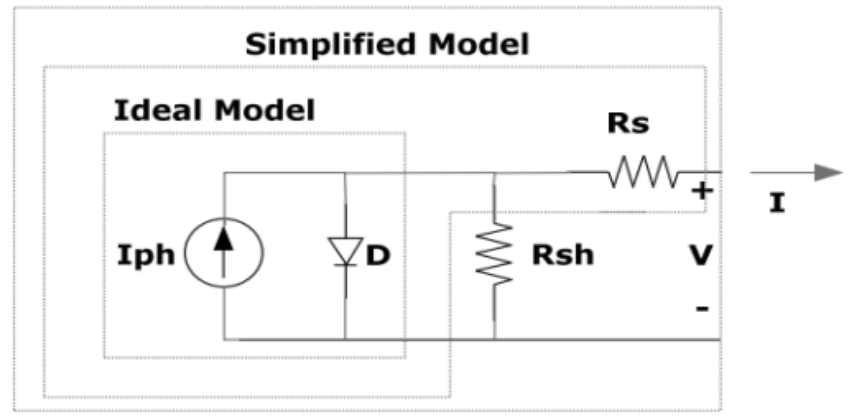

Fig. 1 Electrical equivalent circuit diagram for photovoltaic cell [40].

\section{PV Cell Modeling}

For the simulation process it is important to draw the electrical equivalent network. Fig. 1 explains electrical equivalent circuit for solar cell. The mathematical equation for current of photovoltaic cell is given by Equation (1) [38].

$$
I=I_{p h}-I_{S}\left[\exp \left(\frac{q\left(V+I R_{S}\right)}{k T_{C} A}\right)-1\right]-\frac{V+I R_{S}}{R_{s h}}
$$

Where $I_{p h}$ expresses light generated current, $I_{S}$ represents dark current saturation, $q$ is charge of electron $\left(1.6 \times 10^{-19} \mathrm{C}\right), k$ is Boltzmann's constant $=1.38 \times 10^{-23} \mathrm{~J} / \mathrm{k}, \quad T_{C}$ acts as working temperature of cell, $A$ is ideality factor, $R_{s h}$ is shunt resistance and $\mathrm{R}_{\mathrm{S}}$ is series resistance.

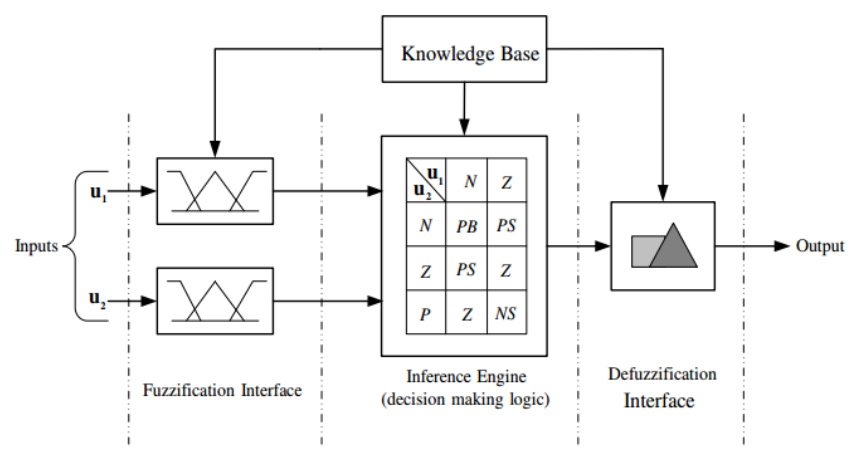

Fig. 2 Basic concept for fuzzy logic control.

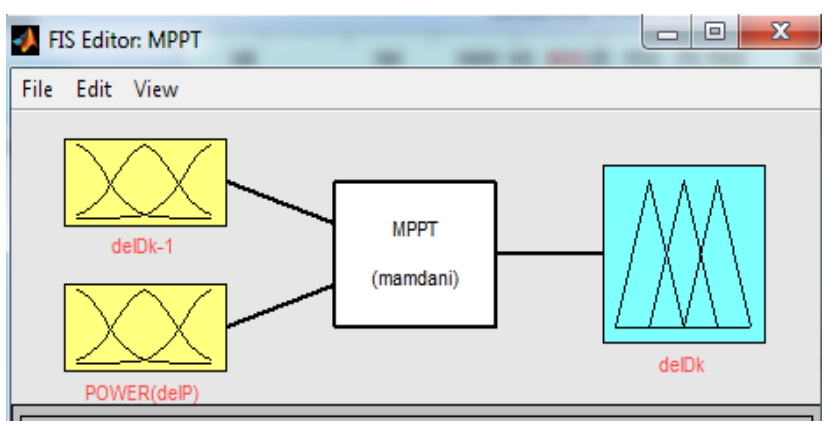

Fig. 3 Simulink model for fuzzy interface.

The photo current depending on the solar radiation and working temperature is provided by Equation (2) [38].

$$
I_{p h}=\left[I_{S C}+K_{I}\left(T_{C}-T_{r e f}\right)\right] \frac{G}{G_{n}}
$$

Where $I_{S C}$ is the short circuit current at $25^{\circ} \mathrm{C}, K_{I}$ is the temperature coefficient of short circuit current, $T_{r e f}$ is the reference temperature and $G$ is the solar radiation in $\mathrm{kW/m}$ and
$G_{n}$ is nominal solar radiation at STC in $k W / m^{2}$. Furthermore, saturation current of cell is shown in Equation (3) [38].

$$
I_{S}=I_{R S}\left(\frac{T_{C}}{T_{r e f}}\right)^{3} \exp \left[\frac{q E_{G}\left(\frac{1}{T_{r e f}}-\frac{1}{T_{C}}\right)}{k A}\right]
$$

Where $I_{R S}$ represents the reverse saturation current at Tref, $E_{G}$ is the band-gap energy.

The reverse saturation current of cell depending on Voc and Isc is given by Equation (4) [39].

$$
I_{R S}=\frac{I_{S C}}{\exp \left(\frac{q V_{O C}}{N s K T C A}\right)-1}
$$

Where $\mathrm{V}_{\mathrm{OC}}=$ the open circuit voltage of the PV cell. The Equation (5) is expressing the thermal voltage.

$$
V_{t}=\frac{k T_{C}}{q}
$$

\section{PV Array Modeling}

The photovoltaic array is defined as the series or parallel arrangement of the photovoltaic modules. The photovoltaic module taken for software simulation produces optimum output of $100 \mathrm{~W}$. For obtaining output power at expected voltage and current, the series and parallel arrangement of the photovoltaic modules needs to be observed accurately. The current equation of the photovoltaic array with $N_{S}$ series and $N_{P}$ parallel is provided by Equation (6).

$$
I=N_{P} I_{p h}-N_{P} I_{S}\left[\exp \left(\frac{q\left(\frac{V}{N_{S}}+\frac{I R_{S}}{N_{P}}\right)}{k T_{C} A}\right)-1\right]-\frac{\frac{N_{P} V}{N_{S}}+I R_{S}}{R_{s h}}
$$

\section{MPPT using Fuzzy}

For implementation of the fuzzy logic some parameters are needed to consider. Fig. 2 shows the overall concept of the fuzzy logic which is implemented to find out the duty cycle in PV system. Here Mamdani controller is used as a decision maker. And centroid method is utilized for defuzzification purpose. Two membership functions are used as the input for this fuzzy controller. These two variables are duty cycle and the power difference. Finally the output parameter is set as the update step size in terms of duty cycle.

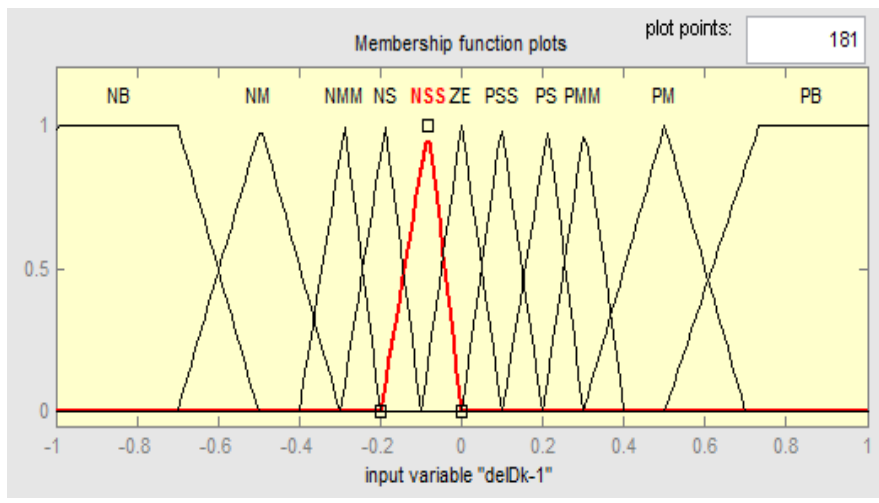

Fig. 4 Membership function of duty cycle input $\Delta D_{k-1}$.

Fig. 3 represents the preview of fuzzy logic controller in MATLAB simulink where two input variables (Duty cycle, Power) are taken as fuzzy input and one output variable (Duty cycle) is taken as fuzzy output. All membership functions are given in Fig. 4 - Fig. 6 respectively. Fig. 4 shows that total eleven 
levels are used for using as the various category of the duty cycle input variable. These levels are treated as NB (Negative big), NM (Negative medium), NMM (Negative medium medium), NS (Negative small), NSS (Negative small small), ZE (Zero), PSS (Positive small small), PS (Positive small), PMM (Positive medium medium), PM (Positive medium), PB (Positive big). Similarly Fig. 5 shows total five levels of variation used as the membership function for the input power difference. And finally Fig. 6 shows that total eleven levels of variation for the output variable as the membership function for the output duty cycle. Furthermore Table 1 shows the rules for decision maker used as Mamdani controller in this paper. The rules are read as If $\triangle P k$ is $N B$ and $\triangle D k-1$ is $N B$ then $\triangle D k$ is $P M$ If $\triangle P k$ is $N B$ and $\triangle D k-1$ is NM then $\triangle D k$ is $P M M$ If $\triangle P k$ is $N B$ and $\triangle D k-1$ is NS then $\triangle D k$ is PSS

\section{If $\triangle P k$ is $P B$ and $\triangle D k-1$ is $P B$ then $\triangle D k$ is $P M$.}

Finally Fig. 7 shows the implementation of fuzzy logic in PV system in the manner of MATLAB simulink model.

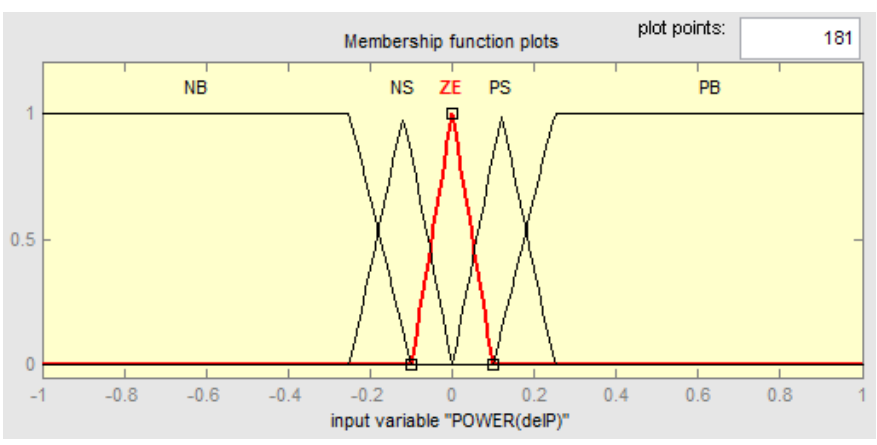

Fig. 5 Membership function of power input $\Delta \mathrm{P}_{\mathrm{k}}$

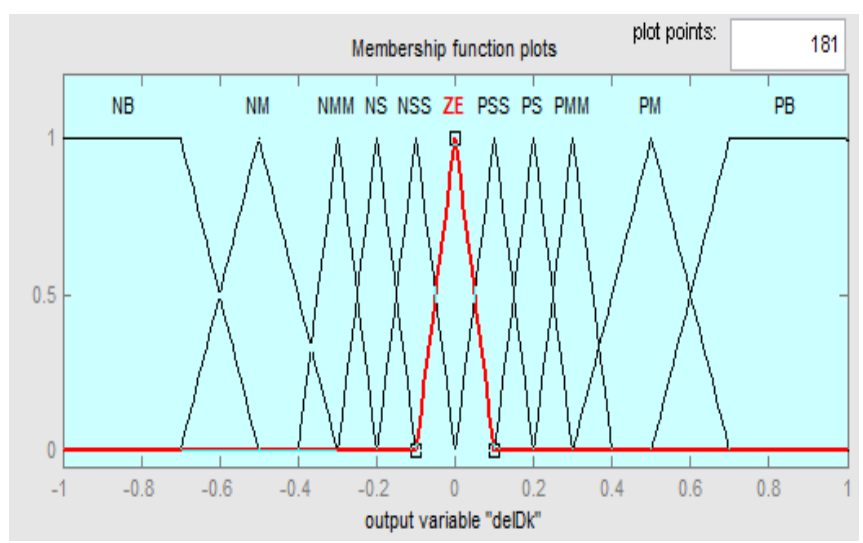

Fig. 6 The membership function of duty cycle output $\Delta D_{k}$

Table 1 Rules for Fuzzy control

\section{$\Delta D k-1$}

NB NM NMM NS NSS ZE PSS PS PMM PM PB

NB PM PMM PS PSS PSS NB NSS NSS NS NMM NM

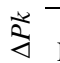

NS PM PMM PS PSS PSS NS NSS NSS NS NMM NM

ZE NB NM NMM NS NSS ZE PSS PM PMM PM PB

PS NM NMM NS NSS NSS PS PSS PSS PS PMM PM

PB NM NMM NS NSS ZE PS PSS PSS PS PMM PM

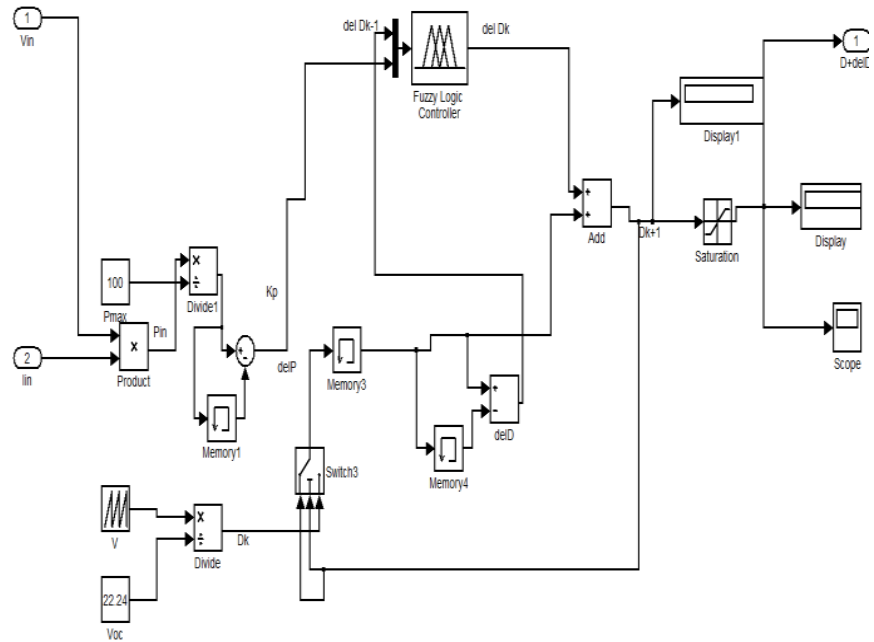

Fig. 7 Fuzzy implementation model in Simulink

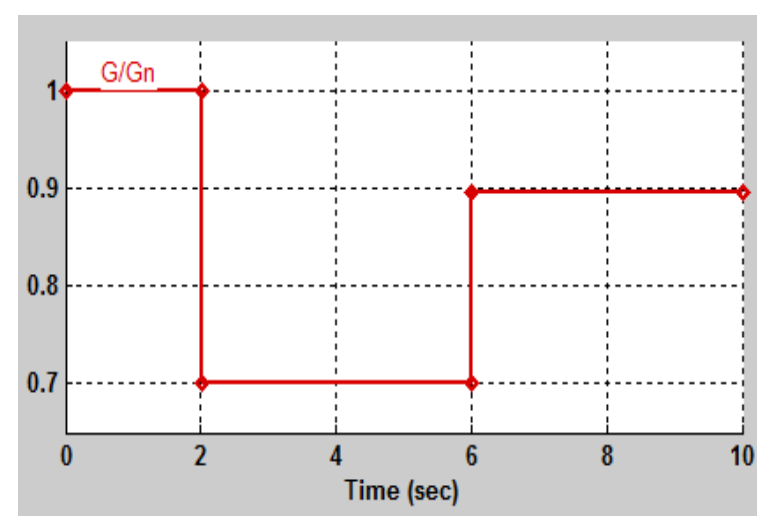

Fig. 8 Irradiance profile for producing partial shading effect.

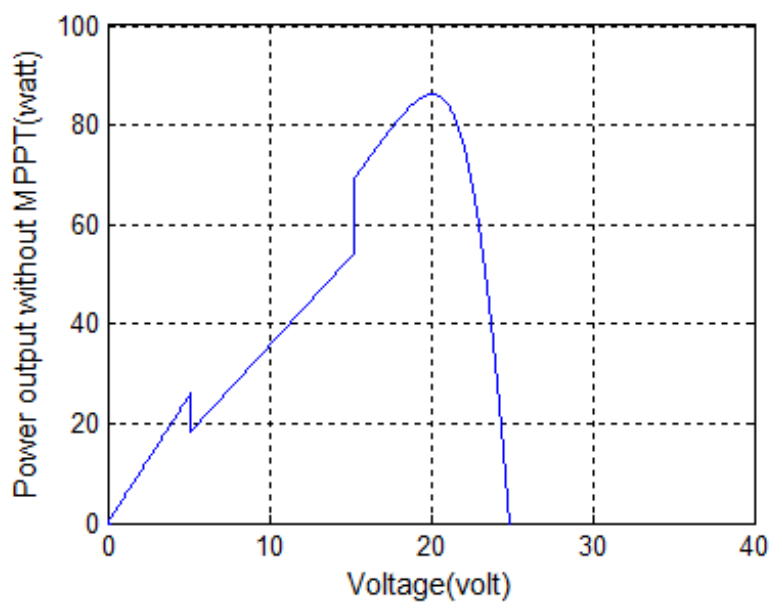

Fig. 9 Output power curve for shading effect without MPPT.

\section{Results from Simulation}

For purpose of simulation, CSS-MSP-100M-36 is taken as solar module. Fig. 8 is standing for showing the solar radiation preview at a certain period to produce the partial shading criteria. The power output is represented by Fig. 9 under the condition of partial shading. From the simulation it is seen that around 87 watt of power can be generated as the maximum. And at around 25 watt of power around 57 watt of power simulation shows deviation of power due to application of the partial shading effect in the PV module. 


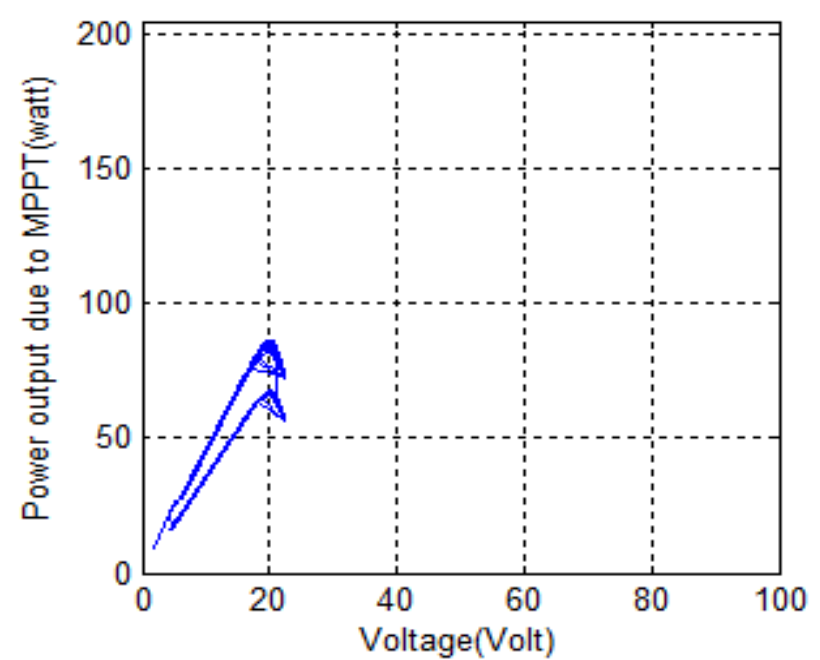

Fig. 10 Output power curve shading effect with MPPT.

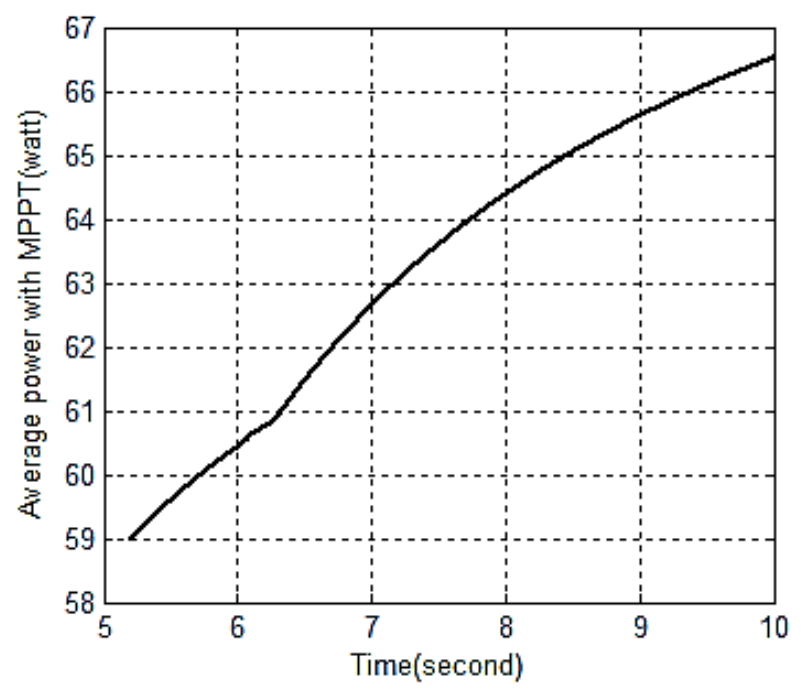

Fig. 11 Average power curve for partial shading effect with MPPT.

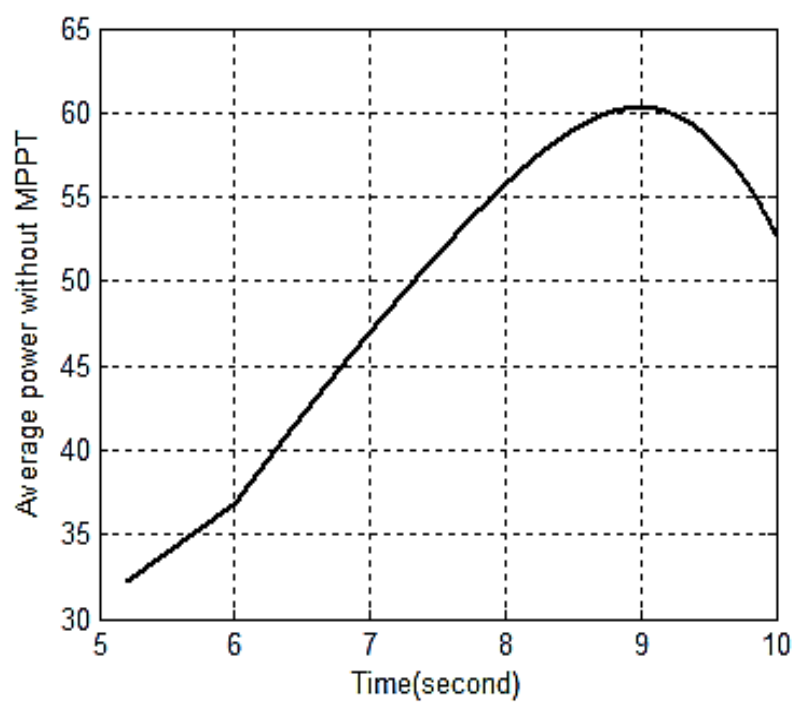

Fig. 12 Average power curve for partial shading effect without MPPT.

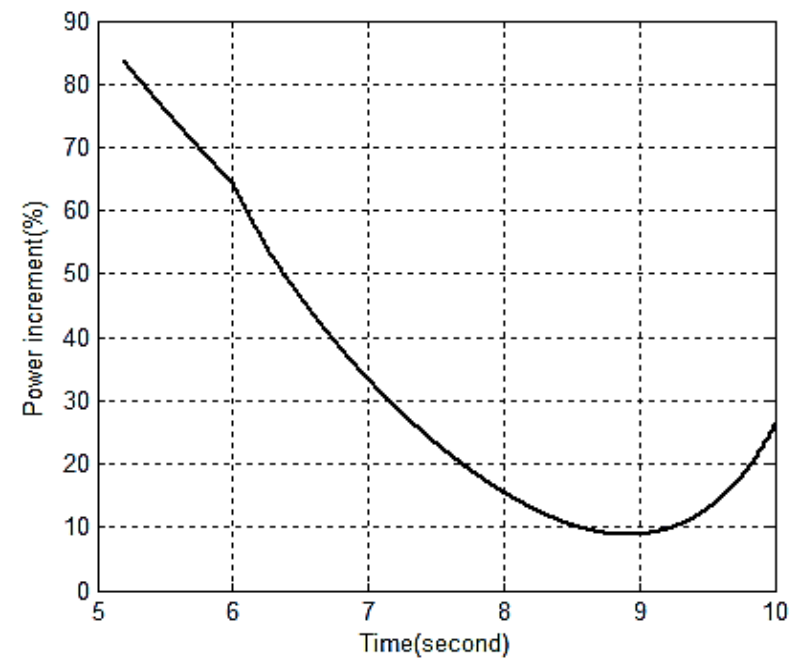

Fig. 13 Development of percentage of power under partial shading effect due to MPPT.

Whereas Fig. 10 is showing the partial shading power profile under MPPT solution handled by fuzzy controller. The simulation obtained in this figure tries to investigate the power with MPPT tracking where two power peaks are obtained at around 87 watt and at around 67 watt of power. From Fig. 11 it is seen that average power is varied in the range of 59 watt to 66.5 watt with MPPT whereas Fig. 12 shows that this range is lying in range of 33 watt to 60 watt without MPPT solution. Finally Fig. 13 represents the output power development in the terms of percentage with MPPT solution for partial shading effect. From the simulation process it is noticed that a lowest power peak is obtained at around $9 \%$ of power development.

\section{Conclusion}

To investigate the power performance under partial shading effect on PV module, fuzzy logic control is used as the MPPT solution. Since fuzzy has a good scope for selection of the step size as the requirement after processing the input variables in the decision making process, it is a good scope to track the maximum power from the PV module. From the MPPT solution it is found that around $84 \%$ as maximum and around $10 \%$ as minimum output power can be developed. Furthermore more research works are needed to seek power output under partial shading. A good number of factors such as temperature, series resistance of PV cell, ideality factor, clearness index etc are needed to observe the overall performance of PV module.

\section{References}

[1] Farhat, M. and Sbita, L., 2011. Advanced fuzzy MPPT control algorithm for photovoltaic systems. Science Academy Transactions on Renewable Energy Systems Engineering and Technology, 1(1), pp.29-36.

[2] Tafticht, T., Agbossou, K., Doumbia, M.L. and Cheriti, A., 2008. An improved maximum power point tracking method for photovoltaic systems. Renewable energy, 33(7), pp.1508-1516.

[3] Philibert, C., Frankl, P., Tam, C., Abdelilah, Y., Bahar, H., Marchais, Q. and Wiesner, H., 2014. Technology roadmap: solar photovoltaic energy. International Energy Agency: Paris, France.

[4] Tomabechi, K., 2010. Energy resources in the future. Energies, 3(4), pp.686-695. 
[5] Ocran, T.A., Cao, J., Cao, B. and Sun, X., 2005. Artificial neural network maximum power point tracker for solar electric vehicle. Tsinghua science and technology, 10(2), pp.204-208.

[6] Hua, C. and Shen, C., 1998, February. Comparative study of peak power tracking techniques for solar storage system. In APEC'98 Thirteenth Annual Applied Power Electronics Conference and Exposition (Vol. 2, pp. 679685). IEEE.

[7] Koutroulis, E., Kalaitzakis, K. and Voulgaris, N.C., 2001. Development of a microcontroller-based, photovoltaic maximum power point tracking control system. IEEE Transactions on power electronics, 16(1), pp.46-54.

[8] Enslin, J.H. and Snyman, D.B., 1992, November. Simplified feed-forward control of the maximum power point in PV installations. In Proceedings of the 1992 International Conference on Industrial Electronics, Control, Instrumentation, and Automation (pp. 548-553). IEEE.

[9] Bodur, M. and Ermis, M., 1994, April. Maximum power point tracking for low power photovoltaic solar panels. In Proceedings of MELECON'94. Mediterranean Electrotechnical Conference (pp. 758-761). IEEE.

[10] Sullivan, C.R. and Powers, M.J., 1993, June. A highefficiency maximum power point tracker for photovoltaic arrays in a solar-powered race vehicle. In Proceedings of IEEE Power Electronics Specialist Conference-PESC'93 (pp. 574-580). IEEE.

[11] Veerachary, M., Senjyu, T. and Uezato, K., 2003. Neuralnetwork-based maximum-power-point tracking of coupled-inductor interleaved-boost-converter-supplied PV system using fuzzy controller. IEEE Transactions on Industrial Electronics, 50(4), pp.749-758.

[12] Ocran, T.A., Cao, J., Cao, B. and Sun, X., 2005. Artificial neural network maximum power point tracker for solar electric vehicle. Tsinghua science and technology, 10(2), pp.204-208.

[13] Bose, B.K., 2002. Modern power electronics and AC drives (Vol. 123). Upper Saddle River, NJ: Prentice hall.

[14] Balasubramanian, G. and Singaravelu, S., 2012. Fuzzy logic controller for the maximum power point tracking in photovoltaic system. International Journal of Computer Applications, 41(12), pp.22-28.

[15] Femia, N., Petrone, G., Spagnuolo, G. and Vitelli, M., 2005. Optimization of perturb and observe maximum power point tracking method. IEEE transactions on power electronics, 20(4), pp.963-973.

[16] Hussein, K.H., Muta, I., Hoshino, T. and Osakada, M., 1995. Maximum photovoltaic power tracking: an algorithm for rapidly changing atmospheric conditions. IEE Proceedings-Generation, Transmission and Distribution, 142(1), pp.59-64.

[17] Zainuri, M.M., Radzi, M.M., Soh, A.C. and Rahim, N.A., 2012, December. Adaptive P\&O-fuzzy control MPPT for PV boost dc-dc converter. In 2012 IEEE International Conference on Power and Energy (PECon) (pp. 524529). IEEE.

[18] Tian, Y., Xia, B., Xu, Z. and Sun, W., 2014. Modified asymmetrical variable step size incremental conductance maximum power point tracking method for photovoltaic systems. Journal of Power Electronics, 14(1), pp.156164.
[19] Alajmi, B.N., Ahmed, K.H., Finney, S.J. and Williams, B.W., 2010. Fuzzy-logic-control approach of a modified hill-climbing method for maximum power point in microgrid standalone photovoltaic system. IEEE transactions on power electronics, 26(4), pp.1022-1030.

[20] Iqbal, A., Abu-Rub, H. and Ahmed, S.M., 2010, December. Adaptive neuro-fuzzy inference system based maximum power point tracking of a solar PV module. In 2010 IEEE International Energy Conference (pp. 51-56). IEEE.

[21] Chin, C.S., Neelakantan, P., Yoong, H.P. and Teo, K.T.K., 2011. Optimisation of fuzzy based maximum power point tracking in PV system for rapidly changing solar irradiance. Transaction on Solar Energy and Planning, 2, pp.130-137.

[22] Radjai, T., Gaubert, J.P. and Rahmani, L., 2014, June. The new FLC-variable incremental conductance MPPT with direct control method using Cuk converter. In 2014 IEEE 23rd International Symposium on Industrial Electronics (ISIE) (pp. 2508-2513). IEEE.

[23] Cheikh, M.A., Larbes, C., Kebir, G.T. and Zerguerras, A., 2007. Maximum power point tracking using a fuzzy logic control scheme. Revue des energies Renouvelables, 10(3), pp.387-395.

[24] Rahmani, R., Seyedmahmoudian, M., Mekhilef, S. and Yusof, R., 2013. Implementation of fuzzy logic maximum power point tracking controller for photovoltaic system. American Journal of Applied Sciences, 10, pp.209-218.

[25] Liu, C.L., Chen, J.H., Liu, Y.H. and Yang, Z.Z., 2014. An asymmetrical fuzzy-logic-control-based MPPT algorithm for photovoltaic systems. Energies, 7(4), pp.2177-2193.

[26] Takun, P., Kaitwanidvilai, S. and Jettanasen, C., 2010, March. Maximum power point tracking using fuzzy logic control for photovoltaic systems. In World Congress on Engineering 2012. July 4-6, 2012. London, UK. (Vol. 2189, pp. 986-990). International Association of Engineers.

[27] Putri, R.I., Wibowo, S. and Rifa'i, M., 2015. Maximum power point tracking for photovoltaic using incremental conductance method. Energy Procedia, 68, pp.22-30.

[28] Sakly, A. and Smida, B., 2012, February. M. Adequate fuzzy inference method for MPPT fuzzy control of Photovoltaic systems. In Proceedings of the 2012 International Conference on Future Electrical Power and Energy systems, Lecture Notes in Information Technology (Vol. 9, pp. 457-468).

[29] Mahamudul, H., Saad, M. and Ibrahim Henk, M., 2013. Photovoltaic system modeling with fuzzy logic based maximum power point tracking algorithm. International Journal of Photoenergy, 2013.

[30] El Khateb, A.H., Rahim, N.A. and Selvaraj, J., 2013. Type-2 fuzzy logic approach of a maximum power point tracking employing sepic converter for photovoltaic system. Journal of Clean Energy Technologies, 1(1), pp.41-44.

[31] Roy, C.P., Vijaybhaskar, D. and Maity, T., 2013, December. Modelling of fuzzy logic controller for variable-step MPPT in photovoltaic system. In 2013 IEEE 1st International Conference on Condition Assessment Techniques in Electrical Systems (CATCON) (pp. 341346). IEEE. 
[32] Natsheh, E.M. and Albarbar, A., 2013. Hybrid power systems energy controller based on neural network and fuzzy logic.

[33] Bos, M.J., Abhijith, S., Aswin, V., Basil, R. and Dhanesh, R., 2014. Fuzzy logic controlled PV powered buck converter with MPPT. Int. J. Adv. Res. Electr. Electron. Instrum. Eng, 3, pp.9370-9377.

[34] Takun, P., Kaitwanidvilai, S. and Jettanasen, C., 2010, March. Maximum power point tracking using fuzzy logic control for photovoltaic systems. In World Congress on Engineering 2012. July 4-6, 2012. London, UK. (Vol. 2189, pp. 986-990). International Association of Engineers.

[35] Agorreta, J.L., Reinaldos, L., Gonzalez, R., Borrega, M., Balda, J. and Marroyo, L., 2009. Fuzzy switching technique applied to PWM boost converter operating in mixed conduction mode for PV systems. IEEE Transactions on Industrial Electronics, 56(11), pp.43634373. http://dx.doi.org/10.1109/TIE.2009.2019567

[36] Alajmi, B.N., Ahmed, K.H., Finney, S.J. and Williams, B.W., 2010. Fuzzy-logic-control approach of a modified hill-climbing method for maximum power point in microgrid standalone photovoltaic system. IEEE transactions on power electronics, 26(4), pp.1022-1030. http://dx.doi.org/10.1109/TPEL.2010.2090903

[37] Jose, P. and Jose, P.R., 2014. Grid connected photovoltaic system with fuzzy logic control based MPPT. International Journal of Engineering and Innovative Technology (IJEIT), 3(8), pp.142-148.

[38] Tsai, H.L., Tu, C.S. and Su, Y.J., 2008, October. Development of generalized photovoltaic model using MATLAB/SIMULINK. In Proceedings of the world congress on Engineering and computer science (Vol. 2008, pp. 1-6).

[39] Gupta, A.K., Gupta, M. and Saxena, R., 2018. Modeling and Comparative Analysis of PV Module with Improved Perturbation \& Observation Based MPPT Technique for PV Applications. Archives of Current Research International, pp.1-12.

[40] Durago, J.G., 2011. Photovoltaic Emulator Adaptable to Irradiance, Temperature and Panel Specific IV Curves. 